\title{
Bariery formuł deliberacyjnych w świetle badania praktyk budżetowania obywatelskiego w Polsce prowadzonych w okresie pandemii COVID-19
}

\section{Streszczenie}

Problematyka artykułu ma wyraźny związek z pandemią COVID-19 i jej negatywnym wpływem na partycypację. W 2020 r. pandemia i związany z nią lockdown czasowo przerwały deliberację w procesach budżetowych w ponad stu polskich miastach. Jednak zarazem w ogólnym pejzażu oraz w kształcie topografii budżetowania obywatelskiego w Polsce wiele się nie zmieniło. Nadal jest to teren dla deliberacji niełatwy, choć jest ona możliwa. Autorzy artykułu podjęli próbę przybliżenia skutków oddziaływania tych elementów ustawowej regulacji budżetów obywatelskich, które nie sprzyjają rozwojowi deliberacji. Wyniki analiz odniesiono do znanej w literaturze modelowej typologii partycypacji w budżetowaniu obywatelskim, z uwzględnieniem przypadków trzech polskich miast.

1 Uniwersytet Pedagogiczny im. Komisji Edukacji Narodowej w Krakowie, Katedra Administracji i Polityk Publicznych, e-mail: jacek.sroka@up.krakow.pl, https://orcid.org/0000-0002-4432-3720

2 Uniwersytet Pedagogiczny im. Komisji Edukacji Narodowej w Krakowie, Katedra Administracji i Polityk Publicznych, e-mail: beata.pawlica@up.krakow.pl, https://orcid.org/0000-0002-2941-7470

3 Uniwersytet Pedagogiczny im. Komisji Edukacji Narodowej w Krakowie, Katedra Administracji i Polityk Publicznych, e-mail: joanna.podgorska-rykala@up.krakow.pl, https://orcid.org/0000-0002-5723-0363 
Słowa kluczowe: budżet obywatelski, partycypacja, deliberacja, jednostki pomocnicze gminy, samorząd terytorialny, głosowanie

Kody klasyfikacji JEL: L38, H72, H70

\title{
Barriers to deliberative formulas based on research of civic budgeting practices in Poland conducted during the COVID-19 pandemic
}

\begin{abstract}
The issues discussed in this article are clearly related to the COVID-19 pandemic and its negative impact on civic participation. In 2020, the pandemic and combined lockdown temporarily interrupted deliberation of budget processes in over a hundred Polish cities. However, not much has changed in the general landscape and in the shape of the topography of civic budgeting in Poland. It is still a difficult area for deliberation, although it is possible. The authors of the article have attempted to present the effects of those elements of the statutory regulation of civic budgets that are not conducive to the development of deliberation. The results of the analyzes were compared to the typology of participation in civic budgeting known in the literature, taking into account the cases of three Polish cities.
\end{abstract} Keywords: civic budget, participation, deliberation, local self-government, auxiliary unit of the municipality, voting

JEL Classification Codes: L38, H72, H70

Pośród wielu wniosków, które dla polityki publicznej można wysnuć z wydarzeń związanych z przebiegiem pandemii COVID-19, są także i takie, które sugestywnie uzmysławiają siłę powiązań problemów społecznych, gospodarczych i politycznych. Część z tych wniosków jawi się jako realne zagrożenia dla demokracji. Wynikają one m.in. z głębszej alienacji jednostek, grup, społeczności, osłabionej gotowości obywateli do partycypacji, a także skłonności niektórych przedstawicieli władz publicznych do decydowania dyskrecjonalnego, w którym głos obywateli uwzględniany jest tylko w takim zakresie, $w$ jakim bezwzględnie wymaga tego prawo, choć $\mathrm{i}$ ono bywa przekraczane, nierzadko w imię rozmaicie definiowanych stanów wyższej konieczności. Pogłębianie się tego niepokojącego trendu może umniejszać partycypację, ograniczając ją w praktyce do różnych form głosowania, w których zawsze przeważa plebiscytarność, a deliberacja ewentualnie odgrywa rolę pomocniczą. Tymczasem lekcja, którą odebraliśmy za sprawą pandemii, skłania do wniosku, że w demokracjach 
- zwłaszcza w obliczu sytuacji kryzysowych - warto poszukiwać rozwiązań partycypacyjnych. Jeśli tego się nie robi, wówczas realna się staje ewolucja systemu w postaci stopniowej erozji poliarchii, np. w kierunku zredukowanej demokracji stanu nadzwyczajnego (por. Dahl, 2019). Ograniczanie uprawnień partycypacyjnych jest zarazem łatwiejsze w obliczu zagrożeń, co pokazywały przykłady z różnych stron świata (Afsahi et al., 2020: 18; Sroka, 2017: 10). W tym kontekście szczególnie interesujące są dalsze losy praktyk deliberacyjnych. Jedną z najbardziej znanych ich form jest budżetowanie partycypacyjne, które w Polsce zostało ustawowo określone nazwą budżetu obywatelskiego.

Wprowadzone w 2018 r. przepisy dotyczące budżetu obywatelskiego stanowią ogólną regulację przedmiotowej procedury, która pozostawia władzom jednostek samorządu terytorialnego względnie dużą swobodę w rozstrzygnięciach odnoszących się do konkretnych sposobów finansowania zamierzeń. Swoboda ta okazuje się jednak pozorna w obliczu ustawowo narzuconej formuły głosowania mieszkańców w celu wyłonienia tych projektów budżetu obywatelskiego, które będą kierowane do realizacji. Ustanowienie głosowania mocno ograniczyło deliberacyjne sposoby wyłaniania projektów, które praktykuje się w wielu krajach i praktykowano je także lokalnie w Polsce przed wprowadzeniem regulacji. Natomiast po jej wprowadzeniu deliberacyjne sposoby uzgadniania decyzji odnoszących się do finansowania projektów stały się rzadziej spotykanym dodatkiem. Tym niemniej istnieją przykłady uzasadniające nadzieję na postęp budżetowej deliberacji w Polsce, przynajmniej w niektórych miastach. Jednak obowiązujące przepisy hamują rozwój w tym kierunku. Dlatego przywołane w artykule przypadki wypada potraktować raczej jako wyjątki potwierdzające regułę.

Za sprawą ustawowej formuły wyłaniania zwycięskich projektów w trybie głosowania mieszkańców proces budżetowania obywatelskiego nabrał cech charakterystycznych dla rozwiązań plebiscytarnych, które ze swej natury są rywalizacyjne. Zahamowaniu ulega tym samym, typowa dla deliberacji, dialogowa partycypacja, którą - zważywszy na generalnie niezaawansowany stan jej rozwoju - ogranicza się niemal w zalążku. Nie służy to spajaniu więzi społeczności lokalnych oraz środowiskowemu usieciowieniu działań ośrodków publicznych w rozumieniu, jakie tego typu relacjom nadają koncepcje oraz praktyki z kręgu policy networks (zob. np. Sroka, 2009: 115-173). Istotnym problemem jest uwidaczniająca się w porównaniach międzynarodowych zależność pomiędzy ograniczaniem rozwiązań partycypacyjnych a autokratyzacją władzy, która stała się wyraźniejsza w związku z pandemią i stan ten zdaje się utrwalać. Przyszłość demokratycznych rozwiązań partycypacyjnych zależy od reakcji obywateli, a przede wszystkich od ich skłonności do aktywizowania się w dialogowej partycypacji (Kavakli, 2021). O to zaś trudniej tam, gdzie także przed 
pandemią uwidaczniały się wyraźne braki we wzorcach kulturowych, instytucjach formalnych i w konkretnych praktykach (por. Ney, Verweij, 2014). Polskę można zaliczyć do kręgu przypadków lokujących się w pewnym oddaleniu - zarówno od żywej i niekłamanej partycypacji, charakterystycznej dla „negocjacyjnych” systemów politycznych o rysach konsensualnych, jak i niemal zupełnego braku partycypacji, ewentualnie jej kontraktowania i „rozgrywania” w systemach „nienegocjacyjnych”, o rysach rywalizacyjnych, w których modelową zasadę wyznacza formuła „zwycięzca bierze wszystko" (por. Lijphart, 1999). Zatem wśród popandemicznych powikłań nie sposób nie uwzględniać niedomagań partycypacji. W badanym przez nas przypadku zagrożeniem jest jej spłycanie, dokonujące się za sprawą sformalizowania trybu wyłaniania projektów w budżetowaniu obywatelskim w drodze głosowania - a więc plebiscytu, którego wykorzystanie redukuje lokalne procesy deliberacyjne.

\section{Głos w dyskusji w nawiązaniu do literatury}

W tekście odwołano się do literatury przedmiotu w sposób dostosowany do treści artykułu, a także do założeń projektu badawczego. Stąd też wynika wyraźna orientacja na, wpisany w projekt, generalny punkt odniesienia, jaki stanowią modelowe ustalenia, których autorami są Y. Sintomer, C. Herzberg, A. Röcke, G. Allegretti. Na podstawie analiz funkcjonowania budżetów partycypacyjnych w 20 miastach świata (m.in. w Płocku) wskazali oni na różnorodność lokalnych praktyk, z uwzględnieniem kryteriów związanych z: (1) efektywnością w wykorzystaniu dostępnych zasobów, (2) (ograniczoną) decentralizacją procesu budżetowania, (3) długofalowym stosowaniem tego narzędzia, (4) formalnym wyodrębnieniem budżetu obywatelskiego, (5) możliwościami komunikowania oraz zakresem uwzględniania informacji zwrotnych (Sintomer et al., 2012: 1-34).

Na podstawie ukierunkowanych w ten sposób badań cytowani autorzy dokonali klasyfikacji sześciu modelowych form budżetowania. W artykule proponuje się pewną (zasadną) korektę w klasyfikacji. Istotę tej propozycji wskazano w akapicie umieszczonym pod rysunkiem 1, a konkluzje umieszczono w podsumowaniu.

Na modelowe spektrum form partycypacji, które występują (nie tylko) w procesach budżetowania obywatelskiego składają się: (1) demokracja partycypacyjna (participatory democracy), (2) bliska demokracja (proximity democracy), (3) partycypacja modernizacyjna (participatory modernization), (4) (neo)pluralizm - partycypacja wielosektorowa (multi-stakeholder participation), (5) (neo)korporatyzm - partycypacja parytetowa (neo-corporatism), (6) rozwój wspólnotowy (community development) (por. Sintomer et al., 2012: 17-27). W cytowanym opracowaniu 
Sintomera i współpracowników przypadek Płocka został zaklasyfikowany do kategorii „partycypacji wielosektorowej”, którą w niniejszym artykule dodatkowo opatrzono terminem „(neo)pluralizm”. Z kolei w przypadku kategorii oznaczonej w korygowanym modelu jako neokorporatyzm w proponowanej modyfikacji nadano jej nazwę „(neo)korporatyzm - partycypacja parytetowa”. Decyzja o wprowadzeniu modyfikacji podyktowana była zamiarem uściślenia klasyfikacji, która wydaje się być metodycznie spójniejsza, gdy jednoznacznie uwzględnia oba klasyczne warianty dialogu społecznego (por. Gardawski, 2009). Zasadność zgłoszonej modyfikacji potwierdzają wyniki wcześniej prowadzonych badań własnych. W artykule wskazano na różnorodność wyrastających z tradycji pluralizmu i korporatyzmu współczesnych form partycypacji i deliberacji (np. Lindell, 2011). Tej mnogości praktycznych rozwiązań nie można jednak porównać do wygodnej „skrzynki narzędziowej”, ponieważ partycypacyjne narzędzia nie są $\mathrm{w}$ równym stopniu ergonomiczne dla wszystkich potencjalnych użytkowników, a dla niektórych są wręcz nie do użycia - z przyczyn dominujących w danej wspólnocie wiążących wzorów zachowań (zob. np. Ehrlich, 1995; Zybała, 2018), ale także z powodów zakorzenionych w indywidualnych typach osobowości (por. Baron-Cohen, 2015; Lindell, Strandberg, 2018). Nierzadko partycypacyjne narzędzia są lokalnie rozmaicie przerabiane, celem zwiększenia ich miejscowej funkcjonalności, czego skutki bywają różne, a wśród negatywnych przeważa plebiscytyzacja wielu procesów.

\section{Rysunek 1. Modele partycypacji w procesach budżetowania obywatelskiego}

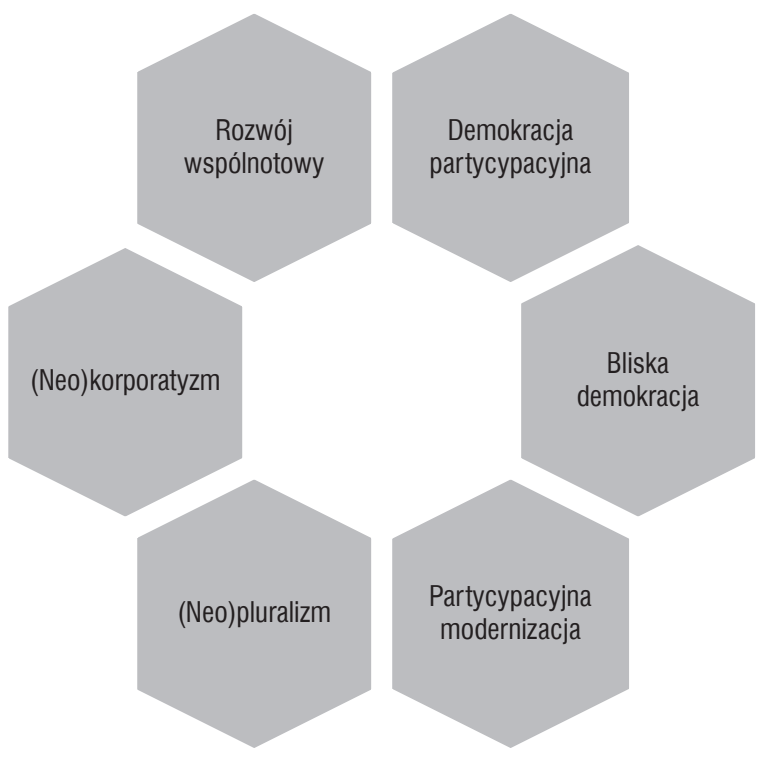

Źródło: opracowanie własne na podstawie Sintomer et al. (2012: 19). 
Odwołanie do kategorii pluralizmu i korporatyzmu oraz dodanie przed nimi, w nawiasach, przedrostka „neo” nawiązuje więc do klasycznych analiz aktywności grup interesu, a zarazem uwzględnia współczesne, labilniejsze formy uzgadniania interesów grupowych - z przewagą rywalizacji (jak w pluralizmie) bądź z wyraźniejszym nastawieniem koordynacyjnym (jak w korporatyzmie) (por. np. Czub, 2018; Kurczewska, Jasiecki, 2017; Witkowska, Kucheryavaya, 2021). Ma to istotne konotacje z podlegającą przeobrażeniom gospodarką, stosunkami pracy, ewolucją ubezpieczeń społecznych itp. W badaniach nie analizowano oddziaływań wspomnianych uwarunkowań, ale też ich nie ignorowano. Stąd także wynika decyzja o proponowanej korekcie w klasyfikacji modelowej. Za jej trafnością przemawia modelowe przyporządkowanie przypadków trzech polskich miast. Uwzględniono je w podsumowaniu artykułu, gdzie w tabeli 1 podano dalsze szczegóły proponowanej modyfikacji oraz wskazano na usytuowanie przypadków: Dąbrowy Górniczej, Gorzowa Wielkopolskiego, Sopotu.

\section{Cel, zasoby źródłowe i metody badawcze}

Celem artykułu jest uwypuklenie oddziaływania tych elementów regulacji, które w praktyce przydają budżetowaniu obywatelskiemu w Polsce cech plebiscytu, a zubażają je w wymiarze deliberacyjnym. Zmierzając do realizacji wytyczonego celem zadania, analitycznie odniesiono się do: (1) dwóch elementów formalnej regulacji oraz ich wpływu na bardziej deliberacyjny lub bardziej plebiscytarny ogólny profil procesów budżetowania obywatelskiego, (2) praktycznych skutków oddziaływania regulacji w wymiarze lokalnym, które diagnozuje się na podstawie zebranych danych oraz w nawiązaniu do (3) wymiaru systemowo-funkcjonalnego.

Rozważono oddziaływanie dwóch elementów nowej regulacji, które wraz z pojawieniem się pandemii COVID-19 zostało jeszcze wzmocnione przez ograniczenia interakcji międzyludzkich:

- podziały terytorialne na tzw. pule - środki budżetu obywatelskiego mogą być dzielone na pule obejmujące całość jednostki i jej części,

- wymóg, aby zadania w ramach budżetu obywatelskiego wybierane były w procedurze bezpośredniego i równego głosowania.

Zasadne jest pytanie o to, czy „plebiscytarność” narzędzia w postaci budżetowania obywatelskiego determinuje jego powierzchowność i stoi w sprzeczności z ideą społeczeństwa obywatelskiego. Było ono ważne już na koncepcyjnym etapie badań, a pandemia COVID-19 tylko zwielokrotniła jego znaczenie. Praca nad sformułowaniem odpowiedzi na wskazane, a także inne projektowe pytania badawcze ma 
charakter zespołowy i wynika z realizacji zadań założonych w projekcie pt. Ewolucja budżetu obywatelskiego $w$ Polsce - w kierunku deliberacji czy plebiscytu? (2019/33/B/ HS5/00353, NCN OPUS 17). Z tego powodu niniejszy artykuł jest w pełnym tego słowa znaczeniu współautorski. Przygotowanie go nie byłoby możliwe bez wcześniej wykonanej kwerendy (desk research) dokumentacji 940 jednostek samorządu terytorialnego o statusie miasta ( $\mathrm{w}$ gminach miejskich, miejsko-wiejskich, miastach na prawach powiatu). Na podstawie analizy danych zebranych w desk research dalsze badania podjęto $\mathrm{w} 12$ miastach, wyselekcjonowanych $\mathrm{z}$ uwzględnieniem trzech kategorii (po cztery jednostki z każdej kategorii): (1) miast, w których przed nowelizacją ustawy nie praktykowano budżetu partycypacyjnego i gdzie ustawowo wprowadzony budżet obywatelski stanowił pierwsze rozwiązanie mające zwiększyć wpływ mieszkańców na kształtowanie części wydatków jednostki, (2) miast, w których budżet partycypacyjny był praktykowany w okresie czterech lat przed ustawowym wprowadzeniem obligatoryjności stosowania budżetu obywatelskiego, czyli został wprowadzony w kadencji samorządowej 2014-2018, (3) miast, w których budżet partycypacyjny był praktykowany na tyle długo (najwcześniej od 2011 r.), że na trwałe wrósł w krajobraz lokalny, zanim ustawowo wprowadzono obligatoryjność jego stosowania. W wyselekcjonowanych 12 miastach (Dąbrowa Górnicza, Gorzów Wielkopolski, Hrubieszów, Kraków, Krosno, Legnica, Nowa Ruda, Opatów, Puławy, Rypin, Sopot, Tuchola) przeprowadzono 60 wywiadów (po pięć w każdym z miast) $\mathrm{z}$ urzędnikami i projektodawcami ${ }^{4}$. W miejscowościach tych wykonano także odpowiednio ukierunkowane badania ankietowe wśród mieszkańców, w trakcie których do września 2021 r. zebrano 1805 wypełnionych ankiet. Uzyskane dotąd wyniki umożliwiły sformułowanie zawartych w artykule wniosków. Konkluzje te wspiera analiza formalno-instytucjonalna, a interpretacyjnie ukierunkowuje metodyka funkcjonalno-systemowa.

W kolejnych trzech częściach przedstawiono (1) argumenty wynikające z normatywnej analizy obowiązującej regulacji formalnej, a także nawiązujące do nich analizy, (2) znaczenia jednostek pomocniczych oraz (3) głosowania, w których wykorzystano fragmenty wywiadów zebranych w Dąbrowie Górniczej, Gorzowie Wielkopolskim i Sopocie. W podsumowaniu odniesiono się do rezultatów analizy

\footnotetext{
4 Przeprowadzone wywiady scenariuszowe miały charakter rozmów indywidualnych, które z powodu pandemii przeprowadzono zdalnie. Narzędzie badawcze przybrało postać dyspozycji do wywiadu, które były zastosowane $\mathrm{w}$ przypadkach pięciu respondentów w każdym $\mathrm{z}$ poddanych eksploracji miast, $\mathrm{w}$ tym: przewodniczącego organu stanowiącego lub jego zastępcy (rada miasta), przedstawiciela organu wykonawczego (wójt, burmistrz, prezydent miasta lub jego zastępca), urzędnika bezpośrednio odpowiedzialnego za proces budżetu obywatelskiego, autora jednego ze zwycięskich projektów, który otrzymał w ostatnim głosowaniu najwięcej głosów, autora projektu, który w ostatniej edycji nie został zakwalifikowany ze względów formalnych/merytorycznych.
} 
uwarunkowań formalno-instytucjonalnych oraz skutków, jakie przynoszą one w lokalnych praktykach. Przedstawiono także wnioski dotyczące wymiaru funkcjonalno-systemowego oraz sformułowano diagnozę dotyczącą przyporządkowania rozpatrywanych przypadków do kryteriów modelowego spektrum partycypacji autorstwa Sintomera i współpracowników, w którym to spektrum piszący zaproponowali autorskie korekty.

\section{Opis rezultatów normatywnej analizy regulacji budżetu obywatelskiego}

Wprowadzając do porządku prawnego regulację instytucji budżetu obywatelskiego, ustawodawca nie zdecydował się na wyczerpujące ujęcie jej procedury, ale na wskazanie najważniejszych zasad. Rozstrzygnięcie części kwestii szczegółowych pozostawił w gestii organów stanowiących jednostek samorządu terytorialnego (jst). Narzucił jednak dwie reguły kluczowe.

W odniesieniu do barier deliberacji wątpliwości budzi formalna konieczność stosowania w budżetowaniu obywatelskim podziału miasta na jednostki pomocnicze. Wiąże się to z podziałem budżetu na pule, a także warunkuje organizację głosowań w okręgach wytyczonych w sposób odpowiadający specyfice lokalnie powołanych jednostek pomocniczych. Dyskusyjny jest także wymóg głosowania, który redukuje partycypację, a wzmacnia plebiscytarność. Wskazane reguły w dłuższej perspektywie mogą blokować samorządy, zwłaszcza te doświadczone, w ich partycypacyjnych praktykach, ograniczając (za sprawą usztywnionej regulacji) wypracowane wcześniej deliberacyjne warianty budżetowania obywatelskiego.

W znowelizowanych w 2018 r. ustawach samorządowych precyzuje się, że budżet obywatelski jest szczególną formą konsultacji społecznych, w ramach których mieszkańcy w bezpośrednim głosowaniu decydują corocznie o części wydatków budżetowych danej jst. Zadania wybrane przez mieszkańców mają być uwzględnione w lokalnej uchwale budżetowej na kolejny rok. W toku prac nad projektem uchwały budżetowej organ stanowiący nie może usuwać lub w sposób istotny zmieniać zadań wybranych w ramach budżetu obywatelskiego.

W gminach będących miastami na prawach powiatu utworzenie budżetu obywatelskiego jest obowiązkowe, a wielkość środków przeznaczonych na ten cel ma wynosić co najmniej $0,5 \%$ wydatków gminy zawartych w ostatnim przedłożonym sprawozdaniu z wykonania budżetu. W przypadkach powiatu i województwa, w których tworzenie budżetów obywatelskich jest fakultatywne, nie wskazano minimalnego progu procentowego. W gminach środki wydatkowane w ramach budżetu obywatelskiego 
mogą być dzielone na pule obejmujące całość gminy i jej części w postaci jednostek pomocniczych lub grup jednostek pomocniczych. W powiatach natomiast środki mogą być dzielone na pule obejmujące całość powiatu i jego części w postaci gmin lub grup gmin, a w województwach - w odniesieniu do całości województwa bądź jego części w postaci powiatów lub grup powiatów. Ustawa stanowi, że o wyborze projektów kierowanych do realizacji decyduje głosowanie przeprowadzane z zachowaniem zasad równości i bezpośredniości.

Do zadań organu stanowiącego należy ustalenie w drodze uchwały wymagań, jakie powinien spełniać projekt budżetu obywatelskiego, w tym: określenie wymogów formalnych dla zgłaszanych projektów, wskazanie wymaganej liczby podpisów mieszkańców popierających projekt (nie może być ona większa niż $0,1 \%$ mieszkańców terenu objętego pulą, gdzie zgłaszany jest projekt), a także przygotowanie kryteriów oceny zgodności z prawem zgłaszanych projektów, ich wykonalności technicznej oraz stawianych wobec nich rygorów formalnych. Wymagane jest także ustalenie trybu odwoławczego od decyzji o niedopuszczeniu projektu do głosowania oraz ustanowienie organizacyjnych szczegółów przeprowadzania głosowania, ustalania jego wyników i podawania ich do publicznej wiadomości.

Uchwała w sprawie określenia wymagań, jakie powinien spełniać projekt budżetu obywatelskiego, może mieć charakter jednorazowy (dla roku budżetowego) lub uniwersalny (dla kolejnych lat budżetowych). Jedną z charakterystycznych i znanych powszechnie także w Polsce cech aktów prawa miejscowego jest to, że te same zadania bywają regulowane w odmienny sposób w różnych jst. Różnorodność ta nie jest przypadkowa i wynika z generalnego postulatu dopasowywania prawa stanowionego do specyfiki uwarunkowań lokalnych, co zwiększa prawdopodobieństwo efektywności wypracowanych rozwiązań. Stąd także wynika różnorodność lokalnych uchwał przyjmowanych w związku z budżetowaniem obywatelskim. Nie są one jednak dowolne i podlegają nadzorowi Regionalnej Izby Obrachunkowej, ponieważ ich treści odnoszą się do finansów publicznych.

Jednostki pomocnicze są organami powoływanymi w ramach tzw. podziału pomocniczego, a ich głównym celem jest zapewnienie wsparcia gminom. W art. 5 ustawy o samorządzie gminnym wskazuje się, że gmina może tworzyć jednostki pomocnicze: sołectwa, dzielnice, osiedla i inne. Jednostką pomocniczą może być również położone na terenie gminy miasto. Ustawodawca decydując się na stwierdzenie „i inne”, ustanowił, że katalog form właściwych dla jednostek pomocniczych nie jest zamknięty, a ich ewentualne dopasowywanie stanowi lokalny przywilej. Wynika to z treści art. 169 ustawy o samorządzie gminnym, w myśl którego organy stanowiące kształtują ustrój wewnętrzny gminy, czyniąc to w granicach ustaw. Rozwiązanie to jest spójne z art. 6 Europejskiej Karty Samorządu Lokalnego, która wskazuje, że 
jeśli ogólniejsze regulacje ustawy nie stanowią inaczej, społeczności lokalne powinny móc samodzielnie ustalać swoją wewnętrzną strukturę administracyjną, tworząc jednostki dostosowane do specyficznych potrzeb i umożliwiające skuteczne zarządzanie (Podgórska-Rykała, Obrębska, 2019: 449-469; Podgórska-Rykała, 2013).

Jednostkę pomocniczą ustanawia rada gminy w drodze uchwały, po przeprowadzeniu konsultacji z mieszkańcami lub z ich inicjatywy. Status prawny jednostki ogólnie regulują art. 35-37b oraz art. 39 i 51 ustawy o samorządzie gminnym. Szczegółowe zasady tworzenia, łączenia, podziału jednostek pomocniczych ma określać natomiast statut gminy. Ustawodawca zobowiązuje zarazem władze gmin do uchwalenia odrębnych statutów dla wszystkich funkcjonujących na ich terenie jednostek pomocniczych. Dokumenty te obligatoryjnie podlegają konsultacjom z mieszkańcami.

Tworzenie przez gminy jednostek pomocniczych to jedna z potencjalnie najefektywniejszych metod wzmacniania więzi we wspólnotach mieszkańców zaangażowanych w lokalne życie publiczne. Dobrze miejscowo dopasowane wykorzystanie tego rozwiązania urealniłoby przekazywanie części planistycznych oraz sprawczych możliwości gmin nie tylko ich składowym terytorialnym, ale także podmiotom mniejszym, np. grupom sąsiedzkim, grupom wsparcia, wolontariuszom itp. Innowacyjne wykorzystanie tej możliwości przybliżałoby mieszkańcom procesy publiczne, sprzyjałoby poczuciu upodmiotowienia i odpowiedzialności za dobro wspólne, a także mogłoby się przyczynić do pozytywnych zmian w postrzeganiu roli decydentów publicznych. Stawką jest realne wcielanie zasady subsydiarności, wciąż przecież w Polsce niełatwej w praktykowaniu, o czym co najmniej od trzech dekad niezmiennie dowiadujemy się z wielu badań i co potwierdzają także najnowsze analizy (zob. np. Pawłowska et al., 2020: 7-167).

Dotąd stosunkowo niewiele polskich gmin zdecydowało się na formalne wyodrębnienie jednostek pomocniczych. Mimo ich braku także przed 2018 r. gminy realizowały procesy budżetowania obywatelskiego $\mathrm{z}$ wykorzystaniem odmiennych podziałów - nie tylko terytorialnych (np. projekty ogólnomiejskie, dzielnicowe, osiedlowe), ale również innych, często dedykowanych grupom wiekowym (dzieciom, młodzieży, seniorom). $\mathrm{Z}$ istnieniem lub brakiem jednostek pomocniczych powiązane są konkretne lokalne praktyki ustawowej zasady głosowania w budżetowaniu obywatelskim. W kolejnych dwóch częściach poddaje się pod dyskusję, udokumentowane w toku badań, praktyczne rezultaty uwarunkowań formalnych, które odnoszą się do powoływania jednostek pomocniczych oraz wyłaniania zwycięskich projektów $\mathrm{w}$ drodze głosowania. Wątki związane z jednostkami pomocniczymi i głosowaniem nie są w badaniach traktowane w sposób rozłączny, ale dla przejrzystości w artykule umieszczono je w dwóch wyodrębnionych fragmentach. 


\section{Znaczenie jednostek pomocniczych w budżetowaniu obywatelskim na przykładach Gorzowa Wielkopolskiego i Sopotu - wstęp do dyskusji}

Przykładem miasta, które praktykuje podziały odmienne od terytorialnych, jest Gorzów Wielkopolski, w którym budżet obywatelski wprowadzono w 2012 r., a w 2020 r. odbyła się jego ósma edycja. Proces realizowany jest nieprzerwanie. Miasto nie wprowadziło formalnego podziału na jednostki pomocnicze, jednak w kolejnych edycjach w latach 2017-2020 projekt mógł zostać zrealizowany w ramach kategorii rejonowej, ogólnomiejskiej lub oświatowej. W każdej z tych kategorii istniała możliwość zgłoszenia zadania o charakterze „twardym” lub „miękkim”. Włodarze miasta są przy tym świadomi znaczenia komunikacji pomiędzy samorządem a mieszkańcami miasta. W ich przekonaniu dobra komunikacja zwiększa prawdopodobieństwo sukcesu projektów zgłaszanych i realizowanych w ramach budżetu obywatelskiego.

Przełomowym rokiem $w$ funkcjonowaniu BO w Gorzowie byt rok 2015, wtedy zaczęliśmy uważniej przygladać się rozwiązaniom, które byty związane z podziałem miasta na okręgi i były tożsame z okreggami wyborczymi. Doszliśmy do wniosku, że taki podział miasta, jeśli chodzi o funkcjonowanie Budżetu Obywatelskiego, nie za bardzo się sprawdza. I właśnie wtedy zaprosiliśmy mieszkańców do wspólnej pracy nad Regulaminem Budżetu Obywatelskiego, chcieliśmy, aby ta dyskusja była dosyć szeroka i miała reprezentacje różnych środowisk. Oczywiście to były prace warsztatowe, w których brali udziat także urzędnicy, przedstawiciele wszystkich klubów radnych, organizacje pozarządowe działające w różnych obszarach. No i oczywiście mieszkańcy, w pracach nad Regulaminem BO brała udział grupa liczaca ponad 40 osób. W efekcie tych prac powstał nowy Regulamin, który został uchwała przyjęty przez Radę Miasta, pojawiło się kilka znaczących zmian. Przede wszystkim dokonaliśmy w Regulaminie nowego podziału miasta na rejony. One nie były już oparte na granicach okręgów wyborczych, ale na jednostkach funkcjonalnych, jednostkach urbanistycznych, które sa utrwalone $w$ świadomości i tożsamości mieszkańców... przestrzennie i funkcjonalnie te rejony tworza też pewną całość. Czyli po prostu już sami mieszkańcy utożsamiali się z danymi osiedlami czy rejonami, $w$ których mieszkali, i je $w$ ten sposób definiowali. I to jest bliskie ich faktycznego funkcjonowania, bo czasami ktoś wcześniej na obrzeżach okręgu wyborczego nie widział potrzeby angażowania się w sprawy innego osiedla, które leżało $w$ jego okręgu. Każdy $z$ tych nowych rejonów ma dedykowana pule środków i może nią dysponować, jeśli chodzi o wydatki związane z BO. W trakcie konsultacji mieszkańcy poprosili o wprowadzenie do BO tzw. projektów miękkich, czyli wydarzeń kulturalnych, sportowych, integracyjnym itp. I trzeba przyznać, że mieszkańcy dość mocno 
postulowali, aby tego typu projekty się w BO pojawily. Przy czym w kategorii ogólnomiejskiej zadania służa całemu miastu. Środki $w$ tej kategorii na działania miękkie powinny być zabezpieczone wyłacznie na te właśnie działania. Aby nie było sytuacji, w której zabraknie środków na tzw. wydarzenie miękkie i aby na przykład (ogólnomiejski - p.a.) koncert nie musiał konkurować z (rejonowym - p.a.) chodnikiem. I właśnie tu mieszkańcy chcieli takiej gwarancji, zabezpieczenia tych środków na zadania miękkie w kategorii ogólnomiejskiej. Natomiast jeśli chodzi o rejony, to grupa warsztatowa stanęła na stanowisku, że tu już ta kategoria projektów miękkich nie zostanie wyodrębniona. I tak to funkcjonuje do dziś - to się sprawdza i jest dobrze oceniane - tak przynajmniej wynika z ewaluacji budżetu obywatelskiego, którą prowadzimy (Gorzów Wielkopolski, z wywiadu z urzędnikiem bezpośrednio odpowiedzialnym za proces budżetowania obywatelskiego).

Niektóre samorządy nie stosują się do przepisów nowelizacji i nie rezygnują z wcześniej wypracowanych rozwiązań. Przykładem jest Sopot - miasto prekursor budżetowania obywatelskiego w Polsce. W Sopocie jedynie w pierwszej edycji budżetu (2011 r.) nie przewidziano podziału na projekty lokalne i ogólnomiejskie. W następnych, na mocy kolejnych uchwał Rady Miasta, mieszkańcy mogli już głosować na projekty ogólnomiejskie oraz lokalne. Okręgi konsultacyjne (w Sopocie nie ma formalnie wyodrębnionych jednostek pomocniczych) wyznaczone były w granicach okręgów wyborczych. Obecnie mieszkańcy mogą zgłaszać projekty w czterech okręgach konsultacyjnych. W związku z wprowadzoną w 2018 r. nowelizacją prawa samorządowego władze miasta powinny znieść głosowanie na projekty lokalne. Jednak tej utrwalonej miejscowo zasady dotąd nie zmieniono, co stoi w kolizji z regulacją ustawową.

Nasz budżet jest podzielony na projekty lokalne i projekty ogólnomiejskie, to jest rzeczywiście trochę nielegalnie, bo u nas nie ma jednostek pomocniczych... według ustawy jak sa jednostki, to może być wtedy ten podział budżetu zastosowany. Ale my, tak trochę cichaczem, mamy ten podział, a wojewoda nam nie uchylił tej naszej uchwały... bo ten podział miasta na okręgi przy budżecie obywatelskim u nas się doskonale sprawdza. I właśnie ta ustawa jest tak skonstruowana, jakby ktoś na siłę chciał poprawiać coś, co się doskonale sprawdza (Sopot, z wywiadu z przedstawicielem lokalnej władzy wykonawczej).

W Sopocie budżet obywatelski został podzielony na dwie pule: to sa projekty ogólnomiejskie - na które przeznaczamy połowę kwoty z BO, czyli 2 miliony złotych i projekty lokalne, na które wydajemy także 2 miliony. W Sopocie formalnie nie ma dzielnic. I po to, aby robić te projekty lokalne, to musieliśmy wymyślić jakiś podział. Pierwszy podział, jaki przyszedł nam do głowy, to jest taki, który wynika z okregów wyborczych, bo one chyba najbardziej odzwierciedlaja terytorialne przyporzadkowanie 
mieszkańców. Ten podział w pewien sposób funkcjonuje wświadomości mieszkańców, na tej zasadzie, że ktoś mówi, że jest z Górnego Sopotu, Dolnego Sopotu, Brodwina czy Kamiennego Potoku. I ten podział na projekty lokalne udało nam się po prostu opisać w uchwale, że to sa okręgi konsultacyjne. Później jeszcze je podzieliliśmy na mniejsze jednostki konsultacyjne, po to, żeby wnioski, które sa przeznaczane do realizacji, byly jeszcze bardziej rozproszone. I teraz mamy cztery okregi konsultacyjne, z czego jeszcze każdy jest podzielony na dwa podokręi: A i B. I jak mamy listę rankingowa tych wniosków, które wygrały w głosowania - to przykładowo: wtedy pierwszy wniosek jest realizowany w podokręu A. Ale już drugi wniosek w takim wypadku musi być realizowany z podokregu B..., czyli tutaj te wnioski realizowane sq naprzemiennie. I czasami się tak zdarza, że na przykład projekty z podokręgu B, gdzie jest większe rozproszenie mieszkańców, nie miałyby żadnych szans na realizację, gdyby właśnie nie ta zasada przemienności. A my doskonale wiemy, że osoby w tych dwóch osiedlach bardzo mocno ze soba konkuruja, ale w jednym $z$ nich jest mniej mieszkańców $i$ (to osiedle - p.a.) byłoby na przegranej pozycji, gdyby nie ta zasada. Tutaj zastosowaliśmy tego rodzaju fortel z konsultacjami i na szczęście nikt nam jeszcze tego nie zakwestionował (Sopot, $\mathrm{z}$ wywiadu $\mathrm{z}$ urzędnikiem bezpośrednio odpowiedzialnym za proces budżetowania obywatelskiego).

\section{Znaczenie głosowania w budżetowaniu obywatelskim na przykładach Dąbrowy Górniczej i Gorzowa Wielkopolskiego - wstęp do dyskusji}

Przykładem miasta, które „zderzyło się” z problemem obligatoryjności głosowania wprowadzonej ustawą, jest Dąbrowa Górnicza. Budżet obywatelski (Dąbrowski Budżet Partycypacyjny) wprowadzono w 2013 r., a w 2020 r. przeprowadzono siódmą edycję. Proces jest realizowany nieprzerwanie, choć ze znaczącymi modyfikacjami. Po czterech edycjach z wykorzystaniem głosowania, w 2017 r. zdecydowano się na innowacyjne rozwiązanie, które realizowano przez następne lata (tzw. DBP 2.0). Polegało ono na zastąpieniu rywalizacji w głosowaniu dialogiem $z$ udziałem mieszkańców osiedli, co praktykowano podczas wielu spotkań, od diagnostycznych po projektowe. Pracom nadawano formę warsztatów. Odbywały się one przy wsparciu animatorów dzielnicowych, którzy przygotowali i prowadzili spotkania z mieszkańcami. Ich zasadniczym celem było ujawnienie, w toku dialogowej dyskusji, potrzeb mieszkańców dzielnic, a także zdiagnozowanie lokalnych deficytów oraz wspólne wypracowanie rozwiązań, które przybierały formę projektów zgłaszanych w ramach budżetu obywatelskiego. 
Zmiany w ustawie o samorządzie gminnym, które zobowiązały miasta na prawach powiatu do wprowadzenia głosowania na projekty, skłoniły władze do podjęcia decyzji o utrzymaniu w mieście dwóch równoległych budżetów, tj. (1) realizowanego mocą zarządzenia Prezydenta Miasta - Dąbrowskiego Budżetu Partycypacyjnego, uznawanego (nie tylko lokalnie) za udany przykład partycypacji oraz (2) Budżetu Obywatelskiego, wdrażanego na podstawie uchwały Rady Miejskiej, przyjętej wg wytycznych ustawowych. W 2020 r. miasto przeznaczyło na budżetowanie obywatelskie $10 \mathrm{mln}$ PLN. W tym na „ustawowy” i ogólnomiejski Budżet Obywatelski - 3,6 mln PLN, a na lokalnie tradycyjny i „osiedlowy” Dąbrowski Budżet Partycypacyjny - 6,4 mln PLN. Rozkład środków pomiędzy obie formy budżetowania wskazuje, że preferowany jest - lokalnie wcześniej wypracowany - Dąbrowski Budżet Partycypacyjny. Projekty zgłaszane w ramach Budżetu Obywatelskiego - ogólnomiejskiego podlegają weryfikacji urzędu miasta, a następnie są wybierane w głosowaniu ogólnomiejskim. Natomiast projekty zgłaszane w ramach Dąbrowskiego Budżetu Partycypacyjnego - osiedlowego (realizowanego z podziałem na 35 osiedli) są wypracowywane na Forach Mieszkańców, podczas warsztatów organizowanych dla mieszkańców poszczególnych osiedli. Na terenie osiedli organizowane są punkty konsultacyjne, w których mieszkańcy mogą zasięgać informacji, zadawać pytania, wymieniać opinie. Działają także wspomniani już animatorzy osiedlowi, których zadaniem jest wspomaganie diagnozowania potrzeb oraz wypracowywania rozwiązań.

Przyjęta przez miasto procedura się sprawdza i choć w opinii przedstawiciela organu wykonawczego nie jest pozbawiona słabych punktów, to: na pewno mocna strona jest, że mieszkańcy miasta zaczęli angażować się w różnego typu przedsięwzięcia. Oczywiście jeśli weźmiemy pod uwage liczby, to tu nie ma jakiegoś wielkiego szału. Ale to ożywienie wśród naszych mieszkańców jest widoczne - no bo tu jednak w grę wchodza prawdziwe pieniądze, prawdziwy budżet, pozwalający na realizację określonych przedsięwzięć. Po drugie, mocna strona jest kwestia edukacyjna - mieszkańcy moga z bliska poznawać, w jaki sposób samorzad, czyli wybrana przez nich władza, realizuje wybrane przez nich przedsięwzięcia. Obserwujemy wtedy ich zdziwienie, że na przykład nie każdy teren $w$ mieście stanowi własność miasta. $Z$ drugiej strony my, jako samorzadowcy, też się poprzez Budżet uczymy... ja obserwuję, że w myśleniu urzędniczym dokonaty się naprawdę duże zmiany na przestrzeni tych ostatnich kilku lat. Ponadto wychodza na jaw te wszystkie niedociagnięcia ze strony urzędników... na przykład, jeśli chodzi o nietrafione decyzje dotyczące wydzielania wspólnot, ale to nie dotyczy tylko Dąbrowy Górniczej, tylko wielu innych samorządów... i to się ujawniało w trakcie dyskusji na temat Budżetu (Dąbrowa Górnicza, z wywiadu z przedstawicielem lokalnej władzy wykonawczej). 
Organizatorzy obu wariantów dąbrowskiego budżetu obywatelskiego starają się stosunkowo szeroko promować tę procedurę. Mimo to, jak wskazał jeden z rozmówców: znaczna część mieszkańców niezbyt dobrze orientuje się w kwestiach BO, a my podajemy o tym informacje w przeróżnych gazetach... na stronach internetowych itp. Ale ta wiedza mieszkańców nie jest generalnie duża. (...) I generalnie stan wiedzy nie jest wysoki, wyjąwszy grupę aktywistów, czyli grupę ok. 700-osobowa - na ogół działaczy w osiedlach albo działaczy organizacji pozarządowych, którzy kwestiami społecznymi w naszym mieście się interesuja (Dąbrowa Górnicza, z wywiadu z przedstawicielem lokalnej władzy wykonawczej).

Znamienne jest zarazem to, że choć miasto stara się inicjować zróżnicowane interakcje z obywatelami, to jednak główny nurt przepływu informacji związany jest $\mathrm{z}$ formami komunikacji pośredniej ${ }^{5}$. Jeden $\mathrm{z}$ naszych rozmówców tak ocenia proces komunikacji z mieszkańcami miasta: my już mamy przećwiczone wszystkie możliwe kanały dystrybucji informacji.. łacznie z internetowymi... doskonale wiemy, jak się tym posługiwać. Oczywiście my się też uczymy, bo kiedyś myśleliśmy, że wystarczy mieć profil na Facebooku, że to jest super wynalazek... dziś już wiemy, że wszystko na Facebooku ginie, a przekazywanie informacji przez stronę internetowa jest mało skuteczne. Ja coraz częściej dochodzę do wniosku, że najskuteczniejsze jest wieszanie ogłoszeń na klatkach schodowych, jeśli chodzi o bloki, a w zielonych dzielnicach - na sklepach spożywczych i w parafiach. Natomiast jeśli chodzi o Internet, to te informacje po prostu gina w szumie informacyjnym (Dąbrowa Górnicza, z wywiadu z przedstawicielem lokalnej władzy wykonawczej).

Jeśli chodzi o nasze działania informacyjne na temat DBP czy BO, to na pewno można byłoby tu coś poprawić w jakości czy formie przekazu. Staramy się blisko wspótpracować ze Spółdzielniami Mieszkaniowymi. Staramy się też stale informować - jeśli $n p$. sa to wydarzenia zwiąane z naborem projektów, to staramy się non stop o nich mówić na Facebooku, na stronie internetowej... I pan prezydent nagrywa filmiki... zamieszczamy też informacje w „Przegladzie Dąbrowskim”, a także w takich ksiązeczkach, które wydaje jedna ze spółdzielni. Staramy się korzystać ze wszelkich możliwych narzędzi, żeby dotrzeć do jak najszerszego grona naszych mieszkańców. Czy można jeszcze coś więcej zrobić na etapie samego informowania o budżecie? Może jeszcze podawanie informacji za pośrednictwem parafii i kościołów - bo tego zaprzestaliśmy po czterech edycjach, jak skończyliśmy z procesem głosowania (jeszcze przed wejściem

5 Według uśrednionych danych z badań ankietowych, przeprowadzanych wśród mieszkańców 12 wytypowanych miast, informacje na temat budżetu obywatelskiego mieszkańcy czerpią z: Internetu $-83,96 \%$, prasy lokalnej $-23,35 \%$, lokalnego radia $-8,96 \%$, informacji umieszczanych w miejscach publicznych $-26,77 \%$, ulotek informacyjnych - 15,92\%, od innych mieszkańców i projektodawców - 35,5\%, z innych źródeł - 4,95\%. 
w życie regulacji ustawowej - p.a.). Oczywiście można jeszcze zrobić akcję wkładania ulotek do każdego mieszkania, ale to chyba będzie mało skuteczne (Dąbrowa Górnicza, z wywiadu z przedstawicielem lokalnej władzy wykonawczej).

Także w Gorzowie Wielkopolskim, z uwagi na nowelizację ustawy wprowadzającą obowiązek formalnego głosowania, podważona została wcześniej wypracowana praktyka rejonowych spotkań z mieszkańcami, podczas których uzgadniano zadania kierowane do realizacji w ramach budżetowania obywatelskiego. Z myślą o złagodzeniu plebiscytowego efektu wspominanej noweli ustawowej wprowadzono tzw. „sieciowanie projektów”. Gorzowskie sieciowanie polega na łączeniu projektów w wyniku rozmów, dyskusji, wymiany argumentów. Ta interesująca lokalna metoda o deliberacyjnych rysach umożliwia projektodawcom, mieszkańcom oraz funkcjonariuszom publicznym dochodzenie do porozumienia w sprawach zgłaszanych projektów, poszukiwanie elementów, które je łączą i w rezultacie kierowanie pod głosowanie projektu „połączonego", który zawiera w sobie istotne cechy kilku projektów wyjściowych. Praktykę tę określa się mianem pakietowania zadań. W związku z brakiem jednostek pomocniczych w mieście, aby zachować ducha istniejącego wcześniej - i zdaniem urzędników sprawdzonego - podziału miasta na rejony i przypisane im pule środków, przekształcono ten podział, korzystając z dopuszczonych przez ustawę kategorii zadań. Określono przy tym maksymalne wartości kosztów realizacji zadań w każdej z kategorii oraz zniesiono możliwość decydowania o etapowaniu zadań, co przed nowelizacją ustawy było praktykowane podczas rejonowych spotkań dyskusyjnych.

W 2016 roku rozpoczęły się spotkania rejonowe $z$ mieszkańcami - bo stwierdziliśmy, że może warto odejść od formuły plebiscytu... głosowania - to jest niekorzystne z ekonomicznego punktu widzenia..., bo jeżeli rozmawiamy o środkach publicznych, to należy w pierwszej kolejności zastanowić się nad priorytetami... A w przypadku głosowania my mamy przede wszystkim do czynienia z mobilizacja i tu na przykład szkoły miały bardzo duża możliwość mobilizacji. W takiej sytuacji wcale nie oznaczało to, że zwycięski projekt wynika z największych potrzeb. I zaobserwowaliśmy, że ta praktyka zaczyna zniechęcać mieszkańców do składania wniosków. Później, w trakcie głosowania, oni nie widzieli sprawczości i przestawali widzieć sens w zgłaszaniu swoich najpilniejszych potrzeb - no bo "i tak wygra boisko przy szkole”. I trzeba było cośz tym zrobić... wszyscy już wiedzieliśmy, że trzeba to jakoś zmienić, jeżeli chcemy, aby $B O$ rzeczywiście służł mieszkańcom..., aby to narzędzie służyło do dokonywania realnych, namacalnych zmian $w$ ich otoczeniu. No i doszliśmy do wniosku, że trzeba w rejonach zaczać rozmawiać o priorytetach, które by uwzględniały takie ekonomiczne, gospodarskie podejście do tych ograniczonych środków. Zaczęliśmy organizować spotkania rejonowe, na których byly prezentowane i omawiane projekty. 
I właśnie te projekty, które były omawiane na spotkaniach, dostawały ekstra punkty, były wyżej oceniane i dostawały większe fory przy głosowaniu. Na spotkaniach rejonowych mieszkańców, $w$ drodze kompromisu, wybierane i realizowane sq zadania dotyczace najpilniejszych zdaniem mieszkańców potrzeb (...) niektóre projekty sa też przesuwane na kolejne lata - tak, aby się zmieścić w kwocie na dany rok. Jeśli udało się osiagnąć kompromis, to tak naprawdę spotkanie rejonowe zamykało temat wyboru zadań na danym osiedlu czy w rejonie. Natomiast jeżeli ten kompromis nie był możliwy, wtedy następowało głosowanie... dla wielu autorów projektów to głosowanie się kończyło niekorzystnie. Ponadto nie było gwarancji, że wygra projekt, który zagospodaruje cała kwotę. Mieszkańcy zaczęli zauważać ten aspekt..., że w takiej sytuacji moga być stratni na rywalizacji i powstał pomysł sieciowania projektów..., czyli łączenia mniejszych projektów w pakiety zadań. No i obecnie jest możliwe pakietowanie zadań do wysokości kwoty, która jest $w$ rejonie. Obecnie mamy do czynienia $z$ mechanizmem wyboru projektów pomiędzy uzgadnianiem a głosowaniem $w$ rejonach. Czasami zdarza się, że na przykład do głosowania staja dwa pakiety... czasami jest to pakiet i jakieśluźne zadanie, którego wnioskodawca nie chciał się spakietować ani też wycofać. No i oczywiście mamy też do czynienia z sytuacja, kiedy wszyscy wnioskodawcy ida $w$ danym rejonie ze swoimi projektami do głosowania - w takiej sytuacji pula niewykorzystanych środków w danym rejonie jest znaczna (Gorzów Wielkopolski, z wywiadu z urzędnikiem bezpośrednio odpowiedzialnym za przebieg procesu budżetowania obywatelskiego).

\section{$* * *$}

Na podstawie zebranego materiału, dotychczas poczynionych analiz, a także w odniesieniu do dyskusji z ustaleniami zawartymi w literaturze, zgłoszono uzupełnienia w spektrum modeli partycypacji w budżetowaniu obywatelskim, które oryginalnie zaproponowali Yves Sintomer, Carsten Herzberg, Anja Röcke, Giovanni Allegretti. Prace nad ostatecznym kształtem propozycji zespołu trwać będą do końca realizacji projektu. Wówczas uogólnienia oraz konstatacje modelowe zyskają pełny wymiar i opatrzone zostaną komentarzami, których nie sposób pomieścić $\mathrm{w}$ formie artykułu.

Trzy uwzględnione w tym tekście przypadki polskich miast lokują się w wariancie tzw. bliskiej demokracji i zakotwiczone są w ramach modeli drugiego nurtu partycypacji, które wyrastają z tradycji klasycznego modelu pluralizmu grup interesu (tabela 1). 


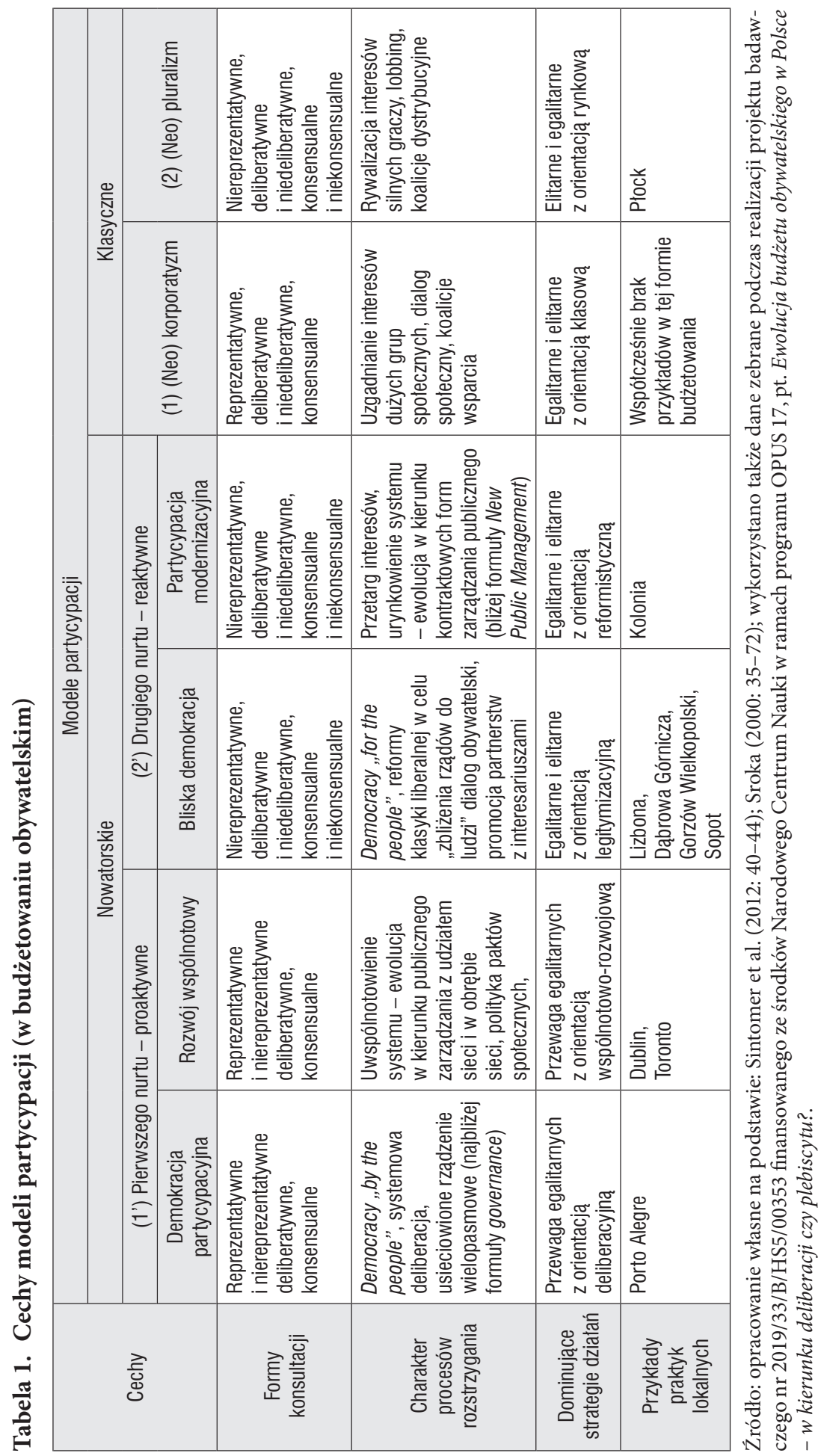


Korzystając z konkluzji, które w odniesieniu do ustaleń Jamesa Fishkina formułuje Viorel Ţuţui, warto podążyć za wskazywanym przez tego drugiego autora - nieco wprawdzie „przykurzonym”, ale jednak poręcznym - rozróżnieniem pomiędzy „demokracją dla obywateli” (democracy "for the people”) oraz "demokracją obywatelską" (democracy „by the people”) (Fishkin, 2009, 2011; Ţuţui, 2015: 190, 200). Ţuţui celnie zwraca uwagę na fakt, że nowożytnych początków tak rozumianej idei demokratycznej partycypacji upatruje się m.in. w słowach wypowiedzianych przez Abrahama Lincolna w 1863 r. w Getysburgu: „rządy ludu, przez lud i dla ludu” - government of the people, by the people, for the people (Lincoln, 1863).

$\mathrm{W}$ tej wizji nad klasycznym, bardziej zachowawczym (reaktywnym) wariantem demokracji reprezentatywnej dominuje podejście wybiegające w przyszłość (proaktywne). Reaktywny wariant zachowawczy (government for the people) sprowadza się do sprawowania władzy „dla obywateli”, a więc „na rzecz obywateli” - za pośrednictwem elit, złożonych $\mathrm{z}$ wyłanianych w wyborach reprezentantów. W podejściu proaktywnym (government by the people) władza jest natomiast sprawowana w bezpośrednim, bliskim oraz sieciowym - w sensie społecznym i technologicznym - kontakcie z jej adresatami. Podejście proaktywne włącza do polityki publicznej rozmaite, żywe w danej (sub) kulturze fenomeny związane ze współdecydowaniem, uzgadnianiem interesów, a także wspólną ewaluacją zbiorowych oraz partykularnych rezultatów i korzyści. Podejście proaktywne, już choćby z uwagi na swój sieciowy paradygmat, wymyka się na tyle ścisłej konceptualizacji formalnej, aby mogła ona stanowić twardą rękojmię dla przepisów prawa.

W tym kontekście ujawnia się przy okazji także jeden z głównych mankamentów stosowania w Unii Europejskiej rozmaitej rangi dokumentów o zróżnicowanej sile oddziaływania, które zalecają (wprost lub pośrednio) „sieciowanie” oraz governance. Realne efekty są jednak bardzo zróżnicowane, o czym przekonuje także przykład budżetów obywatelskich, które wprawdzie nie są bezwzględnie zalecane, ale należą do metod cieszących się wzrastającym poparciem UE. Skuteczne wykorzystanie budżetów obywatelskich jest silnie uwarunkowane miejscowo oraz sytuacyjnie. Jest związane $z$ istnieniem, tworzeniem (oraz zanikaniem i niszczeniem) warunków sprzyjających uporządkowanym dyskusjom oraz wspólnym działaniom publicznym (zob. np. Krenjova, Raudla, 2013: 18-46).

W treści tabeli 1 widać współczesne rozszczepienie klasycznych, wyrastających ze stosunków przemysłowych modeli partycypacji, w postaci korporatyzmu i pluralizmu - na dwa aktualne nurty (proaktywny i reaktywny), które zarazem nie przekreślają swoich pluralistycznych i korporatystycznych pierwowzorów, gdyż te nadal, obok nowszych wariantów, są z powodzeniem realizowane w różnych krajach. I choć mają one skłonność do odwrotów, a nawet bywały w przeszłości już żegnane, 
to jednak przejawiają także udokumentowane skłonności do powracania - falami oraz w nowych odsłonach. Powroty te każdorazowo odciskają znamiona na parametrach systemów politycznych, których profile nabierają rysów bardziej rywalizacyjnych lub bardziej kooperacyjnych (por. np. Baccaro, 2003; Gerlich, 1992; Kelly, 1998; Pennings, 1995; Silver, 2009).

Oznaczony w tabeli 1 jako pierwszy (1) proaktywny nurt innowacyjnych modeli partycypacji nawiązuje do tradycji korporatystycznej koordynacji interesów i lokuje się w obszarze "demokracji obywatelskiej” (democracy „by the people”). Elementy historycznie wcześniej wypracowane w paktującym ze swej natury korporatyzmie są w nim współcześnie pogłębiane, poszerzane i rozwijane w ramach nowatorskich rozwiązań demokracji partycypacyjnej oraz rozwoju wspólnotowego (1'). Dominują w nich proaktywne (wybiegające w przyszłość) współdecydowanie, uzgadnianie interesów oraz uwspólnotowiona ewaluacja korzyści. W nurcie drugim (2), reaktywnym i bliższym idei „demokracji dla obywateli” (democracy „for the people”), zaznaczają się natomiast kontynuacje tzw. pluralizmu grup interesu, $\mathrm{z}$ lobbingiem jako jego wizytówką. Więcej w nim miejsca na reaktywne (bardziej ad hoc) decydowanie, kontraktowanie, rozgrywanie interesów oraz spartykularyzowany przetarg korzyści, choć oczywiście w różnych wariantach oraz z nasileniem typowym dla konkretnych form strategii reaktywnych, charakterystycznych dla wskazanych w tabeli 1 wariantów drugiego nurtu - tj. bliskiej demokracji oraz rozwoju wspólnotowego (2').

Najogólniej mówiąc, łatwiej rozwijające się w nurcie pierwszym strategie egalitarne znajdują realne zastosowanie wtedy, gdy możliwe jest przełamywanie biurokratycznych kanonów, co wiąże się z: (a) decentralizacją i dekoncentracją, (b) przezwyciężaniem skłonności do omnipotencji administracyjnej oraz ograniczaniem aktywności reglamentacyjnej administracji na rzecz przejrzystej sieciowej wymiany zasobów, co skutkuje (c) redukowaniem relacji patronacko-klientelistycznych oraz równoległych stosunków władzy. Z kolei strategie elitarne stosowane są w „odwróconych” warunkach, gdy: (a’) zaznacza się skłonność do centralizacji i koncentracji, (b’) omnipotencja administracji wspierana jej aktywnością reglamentacyjną przyczynia się do powstawania i utrwalania niejawnych sieci dystrybucyjnych, co przyczynia się do (c') wzmacniania relacji patronacko-klientelistycznych oraz rozwoju równoległych stosunków władzy.

Formułowane tu konkluzje swój pełen kształt osiągną po zakończeniu projektu. Już teraz można jednak wstępnie stwierdzić, że zdecydowana większość, jeśli nie wszystkie spośród bliżej zbadanych przez nas budżetów obywatelskich w 12 polskich miastach, będzie się lokować w obrębie reaktywnych wariantów partycypacji - tj. w bardziej nowatorskiej formule tzw. bliskiej demokracji, ewentualnie bliżej klasycznego wariantu pluralistycznego (zob. tabela 1). Nie jest to jednak optymalny 
kierunek ewolucji. Dlatego warto podejmować analityczne oraz praktyczne wysiłki, które realnymi uczyniłyby starania o wyższą jakość partycypacji, deliberacji i współdecydowania w Polsce, nie tylko w budżetowaniu obywatelskim. Rozumianą w ten sposób jakość mogą zapewnić jedynie proaktywne warianty partycypacji (tj. demokracja partycypacyjna, rozwój wspólnotowy). Powodowani optymizmem uznajemy, że m.in. interesująca praktyka „sieciowania projektów” w Gorzowie Wielkopolskim może zapoczątkować tworzenie się w przyszłości sieci wsparcia polityki publicznej (advocacy coalitions), które znane są z praktyk oraz analiz z kręgu policy networks. Jeśli podobna ewolucja okazałaby się możliwa, wówczas - paradoksalnie: sztywne rozwiązania ustawowe mogłyby się okazać zaczynem oddolnych (m.in. sieciujących) prodeliberacyjnych innowacji dostosowawczych, które z czasem wzmogłyby oddolną presję na dokonanie korekt znoszących sztywne uwarunkowania niesprzyjające deliberacji, a wzmacniające rolę plebiscytu w polskim wariancie budżetowania obywatelskiego.

Odnosząc się na koniec do pozaobligatoryjnych możliwości ustanawiania i praktykowania budżetu obywatelskiego, wypada stwierdzić, że w samorządach, które nie podlegają ustawowemu obowiązkowi wprowadzenia budżetu obywatelskiego, przed ewentualnym jego wdrożeniem warto to posunięcie przemyśleć i poddać możliwie szerokiej dyskusji. Nie należy natomiast traktować działań na rzecz wprowadzenia budżetu jako elementu własnej promocji politycznej czy wyborczej, choć niestety bywa, że tak się dzieje. Dla powodzenia deliberacyjnego wariantu budżetowania kluczowe są uwarunkowania miejscowe, sytuacyjne. Niebagatelna jest zasobność materialna, ale dużo ważniejszy od niej jest stan zasobów niematerialnych, które są bardzo istotne, czego najlepszym przykładem jest wysoki poziom uogólnionego zaufania pomnażającego lokalny kapitał społeczny. Deliberacyjny sukces będzie zdecydowanie bliższy tam, gdzie kapitał społeczny sprzyja rozwojowi inkluzywnych sieci społecznych. Jednak podobna sytuacja jest w Polsce rzadko spotykana i z tego pierwszego powodu zalecana jest ostrożność w praktykowaniu budżetu obywatelskiego w tych jednostkach, na których nie ciąży prawny obowiązek. Z dotychczasowych obserwacji wynika, że dbając o stan lokalnego usieciowienia, które dynamizuje partycypację, należy stosować zróżnicowane strategie oraz narzędzia służące konsultacjom i dialogowi - zarówno formalne, jak i nieformalne. W sytuacji optymalnej działania oddolne mieszkańców i organizacji społecznych oraz działania władz i administracji publicznej powinny się w sposób harmonijny uzupełniać, potęgując tym samym efekt kuli śnieżnej w postaci narastania w konkretnym środowisku lokalnym zasobów wzmagających partycypację i urealniających deliberację. Jednak wiele społeczności tkwi w Polsce w zgoła odmiennym położeniu, a niedobory zaufania blokują współpracę, wzmacniają polaryzację, zrywają sieci pomostowe i mocniej wikłają 
aktywnych w relacje o charakterze rywalizacyjnym. Zdecydowana zaś większość pozostaje nieaktywna i zdystansowana, a partycypacja ogranicza się w zasadzie do głosowania $\mathrm{w}$ wyborach samorządowych, w których bierze udział niewielu mieszkańców. W takich realiach należy ostrożnie postępować $\mathrm{z}$ wdrożeniami narzędzi partycypacyjnych - mogą one być błędnie zaprojektowane, ale też błędnie rozpoznane i efekcie w wielu wariantach zniekształcane. Nie wspomaga to partycypacji, a nawet może zwiększać dystans do spraw publicznych i pogłębiać bierność obywatelską. W idealnym świecie jako obywatele nigdy nie powinniśmy mieć dość dyskusji o prodeliberacyjnych innowacjach systemowych. Jednak w świecie realnym często nie ma na dyskusje czasu, ale przede wszystkim brakuje odpowiedniego dla nich języka. Ten zaś kształtuje się i szlifuje nie inaczej, jak w rzeczowych rozmowach oraz otwartym dialogu, na które powinno nas być stać dużo częściej niż na emocjonalne połajanki oraz wygłaszanie własnych poglądów w formach bliskich credo. Budżet obywatelski, tym bardziej w jego obecnym kształcie, nie jest remedium na brak partycypacji, a jedynie jednym ze środków jej wspomagania. W porównaniu do zobligowanych ustawą miast w lepszym położeniu są te samorządy, których nie obejmuje obligatoryjny obowiązek budżetowania obywatelskiego, zwłaszcza gdy partycypacja dotąd nie była w nich na wysokim poziomie. Mogą bowiem, jeśli zechcą, lepiej przygotować grunt pod budżetowanie obywatelskie, wykorzystując inne dostępne narzędzia prawne (np. konsultacje społeczne), a także testując rozwiązania nieformalne oraz adaptując przykłady dobrych praktyk.

\section{Podziękowania}

Nie tylko ze względu na niełatwe warunki kompletowania materiału empirycznego w warunkach pandemii, ale także z uwagi na terminowość i profesjonalizm - szczególne podziękowania należą się współpracownikowi zespołu badawczego, Panu Wiesławowi Zającowi z Biura Analiz Społeczno-Ekonomicznych, bez którego pomocy przebieg badań i ich rezultaty mogłyby być zgoła odmienne.

\section{Źródło finansowania}

Artykuł powstał w związku z realizacją projektu badawczego nr 2019/33/B/ HS5/00353 finansowanego ze środków Narodowego Centrum Nauki w ramach programu OPUS 17, pt. Ewolucja budżetu obywatelskiego w Polsce - w kierunku deliberacji czy plebiscytu?. 


\section{Bibliografia}

Afsahi, A., Beausoleil, E. Dean, R. Ercan, S.A., Gagnon, J.-P. (2020). Editorial: Democracy in a Global Emergency: Five Lessons from the COVID-19 Pandemic. Democratic Theory, 2(7): 5-19. DOI: 10.3167/dt.2020.070201.

Baccaro, L. (2003). What is Alive and What is Dead in the Theory of Corporatism. British Journal of Industrial Relations, 41(4): 683-706.

Baron-Cohen, S. (2015). Teoria zła. O empatii i genezie okrucieństwa. Sopot: Smak Słowa.

Czub, J.F. (2018). Hybrydowy model funkcjonowania grup interesu w Unii Europejskiej. Warszawa: Dom Wyd. ELIPSA.

Dahl, R. (2019). Demokracja i jej krytycy. Warszawa: Alatheia.

Ehrlich, S. (1995). Wiążace wzory zachowania. Warszawa: PWN.

Europejska Karta Samorządu Lokalnego, Dz. U. 1994 Nr 124, poz. 607.

Fishkin, J.S. (2009). When the People Speak. Deliberative Democracy and Public Consultation. Oxford: Oxford University Press.

Fishkin J.S. (2011). Making Deliberative Democracy Practical: Public Consultation and Dispute Resolution. Ohio State Journal on Dispute Resolution, 4(26): 611-626.

Gardawski, J. (2009). Dialog społeczny w Polsce. Teoria, historia, praktyka. Warszawa: Departament Dialogu i Partnerstwa Społecznego MPiPS.

Gerlich, P. (1992). A Farewell to Corporatism. West European Politics, 15(1): 132-146. DOI: $10.1080 / 01402389208424894$.

Kavakli, K.C. (2021). Populist Governments and Democratic Backsliding during the COVID-19 Pandemic, preprint. DOI: 10.13140/RG.2.2.31478.01606.

Kelly, J. (1998). Rethinking Industrial Relations. Mobilization, Collectivism and Long Waves. London: Routledge.

Krenjova, J., Raudla, R. (2013). Participatory Budgeting at the Local Level: Challenges and Opportunities for New Democracies. Halduskultuur - Administrative Culture, 14(1): 18-46.

Kurczewska, U., Jasiecki, K. (red.) (2017). Reprezentacja interesów gospodarczych i społecznych w Unii Europejskiej. Warszawa: Wyd. Uniwersytetu Warszawskiego.

Lijphart, A. (1999). Patterns of Democracy. Government Forms and Performance in Thirty-Six Countries. New Heaven: Yale University Press.

Lincoln, A. (1863). The Gettysburg Address. http://www.abrahamlincolnonline.org/lincoln/ speeches/gettysburg.htm (dostęp: 6.07.2021).

Lindell, M. (2011). Same but Different - Similarities and Differences in the Implementation of Deliberative Mini-publics. https://www.academia.edu/5649973/Same_but_Different_ Similiarities_and_Differences_in_the_Implementation_of_Deliberative_Mini_publics_2011 (dostęp: 04.07.2021).

Lindell, M., Strandberg, K. (2018). A Participatory Personality? Examining the Influence of Personality Traits on Political Participation. Scandinavian Political Studies, 41(3): 239-262. DOI: 10.1111/1467-9477.12118. 
Ney, S., Verweij, M. (2014), Exploring the Contributions of Cultural Theory for Improving Public Deliberation about Complex Policy Problems. The Policy Studies Journal, 42 (4): 620-643.

Pawłowska, A., Kmieciak, R., Kołomycew, A., Radzik-Matuszak, K., Antkowiak, P. (2020). Społeczne rady i komisje jako (nie) obecny uczestnik lokalnego procesu decyzyjnego. Warszawa: Scholar.

Pennings, P. (1995). The Impact of Parties and Welfare Statism. West European Politics, 18(4): 1-17.

Podgórska-Rykała, J., Obrębska, M. (2019). Miejsce jednostek pomocniczych w procesie długookresowego zarządzania miastami wojewódzkimi. Analiza samorządowych aktów planowania (98-111). W: Pozycja ustrojowa organów jednostek samorządu terytorialnego, B. Dolnicki (red.), Warszawa: Wolters Kluwer.

Podgórska-Rykała, J. (2013). Miejsce jednostek pomocniczych gminy w strukturze zdecentralizowanej administracji publicznej (43-58). W: Decentralizacja współczesnego państwa. Wybrane problemy, R. Radek (red.), Katowice: Uniwersytet Śląski.

Silver, B.J. (2009). Globalny proletariat. Ruchy pracownicze i globalizacja po $1870 \mathrm{r}$. Warszawa: Książka i Prasa.

Sintomer, Y., Herzberg, C., Röcke, A., Allegretti, G. (2012). Transnational Models of Citizen Participation: The Case of Participatory Budgeting. Journal of Public Deliberation, 8(2): 1-32. DOI: $10.16997 /$ jdd.141.

Sroka, J. (2000). Europejskie stosunki przemysłowe w perspektywie porównawczej. Wrocław: Wyd. Uniwersytetu Wrocławskiego.

Sroka, J. (2004). Polityka organizacji pracodawców i przedsiębiorców. Wrocław: Wyd. Uniwersytetu Wrocławskiego.

Sroka, J. (2017). Odpływ reprezentacji interesów. Dialog. Pismo Dialogu Społecznego, 3(54): 3-11. https://cpsdialog.gov.pl/images/KWARTALNIKI/54-Dialog-3.2017.pdf.

Ţuţui, V. (2015). Theoretical Models of Deliberative Democracy: A Critical Analysis. Argumentum. Journal of the Seminar of Discursive Logic, Argumentation Theory and Rhetoric, 2(13): 179-205.

Ustawa z dnia 8 marca 1990 r. o samorządzie gminnym, Dz.U. 2020, poz. 71.

Ustawa z dnia 5 czerwca 1998 r. o samorządzie powiatowym, Dz.U. 2020, poz. 920.

Ustawa z dnia 5 czerwca 1998 r. o samorządzie województwa, Dz.U. 2020, poz. 1668.

Witkowska, M., Kucheryavaya, E. (2021). The Concept of Good Governance in the EU Legislation: Analysis in the Context of Methodology of the Civil Law Research. Methodological Problems of the Civil Law Researches, 3(2021): 139-162. DOI: 10.33397/2619-0559-2021-3-3-139-162.

Zybała, A. (2018). Public Policy in Poland in Context of Tendencies Unfolding in Central Europe. Conclusions from Case Studies. Yearbook of the Institute of East-Central Europe, 5(16): 81-103.

Unless stated otherwise, all the materials are available under the Creative Commons Attribution 4.0 International license. Some rights reserved to SGH Warsaw School of Economics.

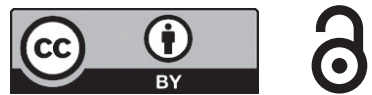

